\title{
DIVERSI BAGI ANAK YANG BERHADAPAN DENGAN HUKUM DI KABUPATEN TANA TORAJA
}

\author{
Christian A Caesar \\ Universitas Kristen Papua, christiancaesar@gmail.com
}

\begin{abstract}
Abstrak
Diversi merupakan penyelesaian perkara anak yang dialihkan dari proses peradilan pidana ke proses di luar peradilan pidana. Hal ini dikarenakan anak merupakan pihak yang belum dapat mempertanggungkawabkan perbutannya secara hukum. Tujuan penelitian adalah untuk menganalisis secara mendalam latar belakang pelaksanaan diversi terhadap anak yang berhadapan dengan hukum serta hambatan yang mempengaruhi pelaksanaan diversi. Penelitian ini menggunakan tipe penelitian hukum normatif empiris dengan mencari data empiris di lapangan yang menyangkut permasalahan yaitu data primer adalah data yang diperoleh langsung dari hasil wawancara dengan responden dan narasumber serta data sekunder adalah data yang diperoleh melalui literatur-literatur yang berkaitan langsung dengan masalah yang dibahas dalam penelitian ini. Hasil penelitian menunjukan bahwa pelaksanaan diversi merupakan bentuk pidana yang beraspek pada pendidikan anak, faktor yang mempengaruhi pelaksanaan diversi dalam restorative justice pada sistim peradilan pidana anak adalah faktor substansi hukum, sumber daya manusia aparat penegak hukum yang belum memahami diversi, dukungan dan kerjasama antar lembaga terkait belum optimal, dan juga korban/keluarga korban belum dapat menerima secara baik mengenai diversi.

Kata Kunci : Diversi; Anak Berhadapan Hukum; Sistem Peradilan Anak
\end{abstract}

\begin{abstract}
Diversion is the settlement of juvenile cases that have been transferred from the criminal justice process to the non-criminal justice process. This is because the child is the party who has not been able to legally account for his dressing. The purpose of the research was to analyse in depth the background execution of the diversion of the dealing with the law and the obstacles affecting the implementation of diversion. This research uses a type of normative empirical legal research by finding the empirical in the field that concerns the problems of primary that is obtained directly from the results of the interviews with respondents and interviewees as well as data secondary data is obtained through literature-literature which deals directly with the issue discussed in this study. The research results give a hint that execution is a form of diversion pemidanaan the more education against children as well as the factors that influence the implementation of restorative justice in the diversion on the criminal justice system, child is a factor the substance of the law, human resource law enforcement officers who have yet to grasp the versioned, support and cooperation among related agencies not optimal, and are also victims/families of the victims have not been able to receive them well on diversion.

Keywords: Diversion; Child Facing the Law; Juvenile Justice System
\end{abstract}

\section{Pendahuluan}

Diversi adalah pengalihan, dimana pelaksanaan diversi dilatarbelakangi keinginan menghindari efek negatif terhadap jiwa dan perkembangan anak oleh keterlibatannya dengan sistem peradilan pidana. Jack E. Bynum dalam bukunya Juvenile Deliquency a Sociological Approach menyatakan "Diversion is an attempt to divert, or channel out, youthful offer from the juvenile justice system" (Diversi adalah sebuah 
tindakan atau perlakuan untuk mengalihkan atau menempatkan pelaku tindak pidana anak keluar dari sistem peradilan pidana). ${ }^{1}$ Restorative Justice adalah bentuk yang paling disarankan dalam melakukan diversi terhadap anak yang berhadapan dengan hukum. Hal ini dikarenakan restorative justice melibatkan berbagai pihak untuk menyelesaikan suatu permasalahan yang terkait dengan tindak pidana yang dilakukan oleh anak. Seorang ahli kriminologi berkebangsaan Inggris, Tony F. Marshall dalam tulisannya berjudul Restorative Justice an Overview, menyatakan bahwa Restorative Justice is a process where by all the parties with a stake in a particular offence come together to resolve collectively how a deal with the aftermath of the offence and it's implication for the future" (Restorative Justice adalah sebuah proses dimana para pihak yang berkepentingan dalam pelanggaran tertentu bertemu bersama untuk menyelesaikan persoalan secara bersama-sama bagaimana menyelesaikan akibat dari pelanggaran tersebut demi kepentingan masa depan). ${ }^{2}$

Anak yang berhadapan dengan hukum dapat juga dikatakan sebagai anak yang terpaksa berkontak dengan sistem pengadilan pidana karena : (1) Disangka, didakwa, atau dinyatakan terbukti bersalah melanggar hukum; atau, (2) Telah menjadi korban akibat perbuatan pelanggaran hukum yang dilakukan orang atau kelompok/lembaga negara terhadapnya; atau (3) Telah melihat, mendengar, merasakan, atau mengetahui suatu peristiwa pelanggaran hukum. ${ }^{3}$ Menurut Abdussalam dan DPM Sitompul, Criminal Justice System atau Sistem Peradilan Pidana adalah suatu sistem dalam proses menentukan konsep sistem yaitu berupa aparatur peradilan pidana yang diikat bersama dalam hubungan antara sub sistem kepolisian, pengadilan, dan lembaga pemasyarakatan. ${ }^{4}$ Menurut Romli Atmasasmita Sistem Peradilan Pidana dapat dilihat dari sudut pendekatan normatif yang memandang keempat aparatur (kepolisian, kejaksaan, pengadilan, dan lembaga pemasyarakatan) sebagai institusi pelaksana peraturan perundang-undangan yang berlaku sehingga keempat aparatur tersebut merupakan bagian yang tidak terpisahkan dari sistem penegakan hukum semata-mata, pendekatan manajemen atau administratif yang memandang keempat aparatur penegak hukum sebagai suatu organisasi manajemen yang memiliki mekanisme kerja, baik hubungan yang bersifat horizontal maupun yang bersifat vertikal sesuai dengan struktur organisasi yang berlaku dalam organisasi tersebut. ${ }^{5}$

Lembaga-lembaga yang menangani perkara anak sesuai dengan UndangUndang Nomor 11 Tahun 2011 tentang Sistem Peradilan Pidana Anak, yaitu

\footnotetext{
${ }^{1}$ Marlina, 2008, Penerapan Konsep Diversi Terhadap Anak Pelaku Tindak Pidana Dalam Sistem Peradilan Pidana Anak, Jurnal Equality, v13n1, hal. 97

${ }^{2}$ Marlina, 2010, Pengantar Konsep Diversi dan Restoratif Justice dalam Hukum Pidana, USU Press, Medan, hal. 28

${ }^{3}$ Apong Herlina, 2004, Perlindungan Terhadap Anak yang Berhadapan dengan Hukum, Buku Saku untuk Polisi, Unicef, Jakarta, hal. 17.

${ }^{4}$ Abdussalam dan DPM Sitompul, 2007, Sistem Peradilan Pidana, Restu Agung, Jakarta, hal. 58

${ }^{5}$ Romli Atmasasmita, 2010, Sistem Peradilan Pidana Kontemporer, Mandar Maju, Bandung, hal. 73
} 
Kepolisian, Kejaksaan, Pengadilan, Lembaga Pemasyarakatan, dan Komisi Perlindungan Anak. Perkara pidana yang dilakukan oleh anak-anak pada umumnya ketentuan yang dilanggar adalah peraturan pidana yang terdapat dalam KUHP. Penyidik perkara anak dilakukan oleh penyidik anak sehingga pada tahap penuntutan juga dilakukan oleh penuntut umum anak dengan syarat-syarat sebagaimana diatur dalam Pasal 41 ayat (2) Undang-Undang Nomor 11 Tahun 2012 tentang Sistem Peradilan Pidana Anak. Dalam proses pemeriksaan di Pengadilan Hakim yang memeriksa dan menyidangkan perkara anak merupakan hakim yang diangkat secara khusus. Dalam hal tempat pelaksanaan hukuman, terdapat Lembaga pemasyarakatan merupakan tempat terpidana untuk menjalani hukuman pidananya baik yang menjalani hukuman penjara maupun kurungan.

Beberapa tanggapan masyarakat mengemukakan bahwa banyak penyidik yang tidak memberikan perhatian secara khusus terhadap tersangka anak dalam peristiwa-perisitwa itu menunjukkan hukum masih belum berpihak pada anak-anak padahal sebagai subjek hukum anak-anak mestinya mendapatkan perlakuan dan perlindungan yang sama dengan orang dewasa bahkan seharusnya anak-anak juga berhak mendaptakan bantuan penasehat hukum/advokat. Polisi dalam sistem peradilan pidana adalah awal dari proses untuk memeriksa anak yang perbuatannya menyangkut berkenaan dengan hukum pidana. Polisi mempunyai suatu otoritas legal yang disebut diskresi, dimana dengan otoritas tersebut polisi berhak meneruskan atau tidak meneruskan suatu perkara.

Tujuan dan dasar pemikiran peradilan pidana anak adalah untuk mewujudkan kesejahteraan anak yang pada dasarnya merupakan bagian dari kesejahteraan sosial. Akan tetapi menurut Muladi bukan berarti bahwa kepentingan atau kesejahteraan anak berada di bawah kepentingan masyarakat justru harus dilihat bahwa mendahulukan atau mengutamakan kesejahteraan atau kepentingan anak itu pada hakikatnya awal dari usaha mewujudkan kesejahteraan sosial. ${ }^{6}$ Kepentingan anak tidak boleh dikorbankan demi kepentingan masyarakat.

Berdasarkan latar belakang tersebut, permasalahan yang akan diteliti dalam penulisan ini adalah dan bagaimana penerapan diversi terhadap anak yang perbuatannya melanggar hukum pidana dan faktor yang mempengaruhi pelaksanaan Diversi terhadap anak yang perbuatannya melanggar hukum pidana.

\section{Metode}

Jenis penelitian ini adalah penelitian hukum normatif empiris dengan mencari data empiris di lapangan. Lokasi penelitian dilakukan di Kabupaten Tana Toraja dalam lingkup Kepolisian Resor Tana Toraja, Kejaksaan Negeri Makale, Pengadilan Negeri Makale dan Rumah Tahanan Kabupaten Tana Toraja. Populasi pada penelitian ini merupakan objek, individu, gejala, kejadian, dan unit yang diteliti.

\footnotetext{
${ }^{6}$ Muladi dan Barda Nawawi Arif, 1992, Teori-Teori dan Kebijakan Pidana, Alumni, Bandung,hal. 111
} 
Penentuan sampel menggunakan metode purposive sampling, yaitu pengambilan sampel berdasarkan ciri-ciri tertentu. Kriteria yang diambil yaitu Kepolisian, Unit PPA (Perlindungan Perempuan dan Anak) Penuntut umum di Kejaksaan, Pengadilan Negeri dan Lembaga pemasyarakatan. Penelitian ini adalah penelitian hukum normatif empiris dengan jenis data primer dan data sekunder. Metode pengumpulan data yang digunakan dalam penelitian ini menyesuaikan dengan jenis data yang digunakan. Dalam memperoleh data primer dilakukan dengan cara wawancara langsung dengan responden dan narasumber serta dengan mengumpulkan bahanbahan sekunder seperti peraturan perundang-undangan, buku, jurnal hukum, hasil penelitian dan sebagainya. Teknik Analisis Data. Data yang telah dikumpulkan dianalisis secara deskriptif kualitatif untuk menjawab masalah.

\section{Pelaksanaan Diversi terhadap Anak yang berhadapan dengan Hukum}

Pengadilan bagi anak yang berhadapan dengan hukum menjadi upaya terakhir setelah berbagai upaya yang dilakukan dengan pendekatan kekeluargaan telah ditempuh. Dalam restorative justice metode yang dipakai adalah musyawarah pemulihan dengan melibatkan korban dan pelaku beserta keluarga masing-masing, ditambah wakil masyarakat yang diharapkan dapat mewakili lingkungan dimana tindak pidana dengan pelaku anak tersebut terjadi. Beberapa manfaat yang dapat diperoleh dari keadilan restorative adalah anak sebagai pelaku, korban, dan saksi akan dilindungi oleh sistem peradilan anak yang ramah. Proses restorative justice pada dasarnya merupakan upaya pengalihan dari proses peradilan pidana menuju penyelesaian secara musyawarah yang pada dasarnya merupakan jiwa dari bangsa Indonesia untuk menyelesaikan permasalahan dengan cara kekeluargaan untuk mencapai mufakat.

Secara konseptual hukum anak adalah seseorang yang berusia dibawah 18 tahun yang berhadapan dengan sistem peradilan pidana dikarenakan yang bersangkutan disangka atau dituduh melakukan tindak pidana. Secara nasional defenisi anak menurut peraturan perundang-undangan menjelaskan anak adalah seorang yang belum mencapai usia 21 tahun (dua puluh satu tahun) atau belum menikah. Undang-undang Nomor 23 Tahun 2002 tentang Perlindungan Anak dalam Pasal 1 angka 1 menjelaskan bahwa anak adalah seseorang yang masih didalam kandungan. Rumusan tersebut tentang batas usia minimal anak 12 tahun sesuai dengan Putusan Mahkamah Konstitusi (MK) Nomor 1/PUU-VIII/ 2010 yang sebelum putusan Mahkamah Konstitusi tersebut usia minimal anak 8 (delapan) tahun.

Undang-Undang Nomor 11 Tahun 2012 tentang Sistem Peradilan Pidana Anak, dalam Bab I Ketentuan Umum Pasal 1 angka 2 disebutkan bahwa : "Anak yang berhadapan dengan Hukum adalah anak yang berkonflik dengan hukum, yaitu anak yang menjadi korban tindak pidana, dan anak yang menjadi saksi tindak pidana."Sistem peradilan anak yang sekarang berlandaskan pada keadilan retributive 
dan restitutif hanya memberikan wewenang kepada Negara yang didelegasikan pada aparat penegak hukum (Polisi, Jaksa, Hakim dan Bapas). Pelaku anak yang berhadapan dengan hukum dan korbannya sedikit sekali mendapat kesempatan untuk menyampaikan versi keadilan yang mereka inginkan. Undang-Undang Sistem Peradilan Anak mulai diberlakukan dua tahun setelah tanggal pengundangannya, yaitu 30 Juli 2012 sebagaimana disebut dalam Ketentuan Penutupnya (Pasal 108 Undang-Undang Sistem Peradilan Pidana Anak). Artinya Undang-Undang Sistem Peradilan Anak ini mulai berlaku sejak 31 Juli 2014.

\subsection{Pelaksanaan Diversi terhadap Anak yang Berhadapan dengan Hukum di Polres}

\section{Tana Toraja.}

Kepolisian merupakan lembaga pertama menangani anak yang berkonflik dengan hukum dalam menyelesaikan kasus anak. Penyidik kepolisian wajib mengupayakan diversi sesuai yang diamanahkan Undang-Undang Sistem Peradilan Pidana Anak. Telegram Kabareskrim No. 1124/XI/2006 tentang Pedoman Pelaksanaan Diversi Bagi Kepolisian. Kewenangan diskresi kepolisian (Pasal 18 ayat (1) Undang-Undang Nomor 2 Tahun 2002 tentang Kepolisian Negara Republik Indonesia selanjutnya disebut Undang-Undang Kepolisian) dengan syarat tindakan tersebut benar-benar diperlukan, tindakan yang diambil benar-benar untuk kepentingan tugas kepolisian, tindakan tersebut adalah tindakan yang tepat untuk mencapai tujuan, berdasarkan asas keseimbangan yaitu mempertimbangkan sifat perbuatan anak dengan akibat yang ditimbulkannya serta tetap memperhatikan kepentingan terbaik demi tumbuh kembang anak.

Prinsip diversi yang terdapat dalam konvensi hak-hak anak yaitu suatu pengalihan bentuk penyelesaian dari penyelesaian yang bersifat proses pidana formal ke alternative penyelesaian dalam bentuk lain yang dinilai terbaik demi kepentingan anak. Dasar hukum penerapan diversi adalah pasal 16 ayat (1) huruf L UndangUndang Kepolisian yang berbunyi ; “Mengadakan tindakan lain menurut hukum yang bertanggung jawab dengan batasan bahwa tindakan tersebut tidak bertentangan dengan hukum yang berlaku, selaras dengan kewajiban profesi yang mengharuskan dilakukannya tindakan jabatan tersebut, tindakan tersebut harus patut dan masuk akal dan termasuk dalam lingkup jabatannya, didasarkan pertimbangan yang layak berdasarkan keadaan yang memaksa dan menghormati hak asasi manusia. Untuk mengetahui pelaksanaan diversi di jajaran Polres Tana Toraja dapat dilihat pada tabel berikut ini :

Tabel 1. Pelaksanaan Diversi di Polres Tana Toraja (2016 - 2018(.Feb)

\begin{tabular}{|c|c|c|c|c|}
\hline No & Tahun & Jumlah perkara masuk & Diversi & Sisa \\
\hline 1 & 2016 & 9 & 6 & 3 \\
2 & 2017 & 12 & 9 & 3 \\
\hline
\end{tabular}




\begin{tabular}{|c|c|c|c|c|}
\hline 3 & $2018(\mathrm{Feb})$ & 8 & 4 & 4 \\
\hline \multicolumn{2}{|c|}{ Jumlah } & 29 & 19 & 10 \\
\hline
\end{tabular}

Sumber data : Polres Tana Toraja, Tahun 2018

Tabel di atas terlihat bahwa jumlah perkara yang masuk dalam kurun waktu tahun 2016 - Februari 2018 sebanyak 29 kasus, dan yang berhasil diversi adalah sebanyak 19 kasus, ini berarti masih tersisa 10 besar untuk dilanjutkan pada proses hukum selanjutnya yaitu lembaga Kejaksaan Negeri Tana Toraja.

\subsection{Pelaksanaan Diversi terhadap Anak yang Berhadapan Dengan Hukum pada}

\section{Kejaksaan Negeri Tana Toraja.}

Kejaksaan sebagai lembaga penuntutan senantiasa dituntut untuk menjalankan fungsinya secara professional di bidang penegakan hukum. Berdasarkan data yang ada dalam kurun waktu tahun 2016 -2018 (Februari), Polres Tana Toraja terdapat sebanyak 10 kasus anak terlihat dalam table berikut ini :

Tabel 2.Pelaksanaan Diversi Terhadap Anak yang Berhadapan dengan Hukum pada Kejaksanaan Negeri Tana Toraja (2016 - 2018 (Februari)

\begin{tabular}{|c|c|c|c|c|}
\hline No & Tahun & Jumlah kasus yang dibina & Diversi & Sisa \\
\hline 1 & 2016 & 3 & 1 & 2 \\
2 & 2017 & 3 & 1 & 2 \\
3 & $2018(\mathrm{Feb})$ & 4 & 2 & 2 \\
\hline \multicolumn{2}{r|}{ Jumlah } & 10 & 4 & 6 \\
\hline
\end{tabular}

Sumber Data : Kejaksaan Negeri Tana Toraja, Tahun 2018

Tabel tersebut diatas menunjukan bahwa dari 10 kasus yang diterima oleh Kejaksaan Negeri Tana Toraja dalam kurun tahun 2016 - 2018 (Februari), telah berhasil didiversi sebanyak 4 kasus. Ini berarti bahwa masih ada 6 kasus lagi yang harus dilimpahkan ke Pengadilan Negeri Makassar untuk disidangkan.

\subsection{Pelaksanaan Diversi pada Pengadilan Negeri Makale (2016 - 2018) (Februari)}

Pelaksanaan diversi yang ditangani oleh Pengadilan Negeri Makale dalam kurun 2016-2018 (Februari), pihak Pengadilan Negeri Makale mendapat limpahan 6 kasus anak yang berhadapan dengan hukum dari pihak Kejaksaan Negeri Tana Toraja untuk disidangkan.Adapun kasus limpahan tersebut yang berhasil didiversi oleh Pihak Pengadilan Negeri Makale, terlihat dalam tabel berikut ini : 
Tabel 3.Pelaksanaan Diversi pada Pengadilan Negeri Makale Periode 2016 - 2018 (Februari)

\begin{tabular}{|c|c|c|c|c|}
\hline No & Tahun & Perkara yang masuk & Diversi & Sisa \\
\hline 1 & 2016 & 2 & 1 & 1 \\
2 & 2017 & 2 & 1 & 1 \\
3 & $2018(\mathrm{Feb})$ & 2 & 1 & 1 \\
\hline \multicolumn{2}{r|}{ Jumlah } & 6 & 3 & 3 \\
\hline
\end{tabular}

Sumber Data : Pengadilan Negeri Makale, Tahun 2018

Dari tabel3, menunjukan bahwa dari 5 kasus yang dilimpahkan oleh pihak Kejaksaan Negeri Tana Toraja, pihak Pengadilan Negeri Makale telah berhasil melaksanakan diversi sebanyak 3 kasus. Salah satu contohnya anak yang bernama Agustinus Tuda Rapa' alias Agus tindak pidana anak dengan register perkara No. 2/Pid.Sus.Anak/2018/PN.MAK yang berhasil dilakukan upaya diversi pada tingkat Pengadilan Makale, bahwa anak tersebut diduga melakukan tindak pidana yang diatur dalam pasal 363 Ayat (1) ke-3 dan 4 KUHPidana. Bahwa pada saat persidangan anak tersebut mengakui kesalahannya serta orang tua anak meminta maaf kepada pihak korban dan pihak korban bersedia memaafkan pelaku. Bahwa untuk selanjutnya masih tersisa 3 kasus yang lanjut pada proses persidangan selanjutnya.

\section{Faktor-Faktor yang Mempengaruhi Pelaksanaan Diversi terhadap Anak yang Berhadapan dengan Hukum}

\subsection{Faktor Substansi Hukum.}

Berdasarkan hasil wawancara penulis dengan Kanit PPA Polres Tana Toraja dapat disimpulkan bahwa faktor penghambat proses pelaksanaan diversi : (1) Ada tumpang tindih pengaturan pelaksanaan diversi, bahwa diversi wajib dilakukan pada tiap tingkatan, tapi ada pengecualian, (2) Proses diversi keterlibatan anak pada pidana tidak menimbulkan korban seperti judi ataupun penggunaan narkoba belum diatur secara jelas diundang-undang.Kendala yang dihadapi oleh pihak kepolisian terkait substansi hukum, yakni belum adanya Peraturan Kepala Kepolisian Negera RI yang mengatur tentang Pedoman Pelaksanaan Diversi dalam Sistem Peradilan Pidana Anak (sebagaimana yang dimiliki oleh para hakim dengan adanya Perma RI Nomor 4 Tahun 2014.

Undang-Undang Sistem Peradilan Pidana Anak belum mengatur secara jelas tentang tata cara dan tahapan proses diversi, sehingga peraturan internal dikalangan kepolisian menjadi kebutuhan yang sangat mendasar dalam upaya implementasi diversi dalam perkara anak. Dalam perspektif substansi hukum, petunjuk teknis pelaksanaan diversi belum semuanya lengkap. Hal ini dapat diatasi dengan cara membuat Peraturan Pemerintah (PP) tentang diversi sebagaimana diatur dalam Pasal 15. Ketentuan Peraturan Pemerintah yang ditindaklanjuti dengan peraturan yang 
lebih rendah tingkatannya juga penting mengingat ada beberapa norma dalam Undang-Undang Sistem Peradilan Pidana Anak yang multi tafsir.

\subsection{Faktor Sumber Daya Aparat Penegak Hukum.}

Sumber daya aparat yang dimaksudkan adalah pemahaman aparat mengenai diversi itu sendiri. Menurut Andarias Toding Datu, salah seorang advokat di Tana Toraja bahwa kendala yang selama ini dihadapi diinstansi aparat penegak hukum dalam melakukan upaya diversi diantaranya yaitu kurangnya pemahaman penyidik khususnya yang menangani kasus anak yang berkonflik dengan hukum. Contohnya Polisi dalam menangani kasus-kasus ringan yang dilakukan oleh anak lebih banyak diproses secara hukum (pidana) ini disebabkan kurangnya pemahaman penyidik terhadap aturan yang ada.

Diversi menurut Undang-Undang Sistem Peradilan Pidana Anak menegaskan bahwa diversi adalah pengalihan penyelesaian perkara anak dari proses peradilan pidana ke proses di luar peradilan pidana. Pemahaman yang keliru merupakan pemahaman yang sering disalah artikan oleh para penyidik khususnya adalah damai tidak meneruskan perkara sampai sidang pengadilan, pemahaman yang salah apabila itu diartikan diversi adalah damai oleh pihak aparat penegak hukum sendiri karena banyak alasan yang malah membuat anak pelaku tindak pidana takut dan mengiyakan apa yang diminta oleh aparat penegak hukum dengan perkataan pilihan "ingin damai atau dihukum dan masuk penjara".

Terbatasnya pemahaman aparat terkait bunyi Undang-Undang Sistem Peradilan Pidana Anak, berkolerasi sangat erat dengan sedikitnya kesempatan bagi para petugas penyidik anak untuk dapat menjalani proses pendidikan dan pelatihan peningkatan kapasitas aparat penegak hukum dalam pelaksanaan penanganan anak berkonflik dengan hukum. Hal ini tentunya juga berimbas pada minimnya petugas khusus anak yang bersertifikat di lingkungan institusi kepolisian, kejaksaan, dan pengadilan.Sementara kendala yang juga dialami di Bapas pada empat lokasi penelitian adalah ketersediaan SDM yang cukup dalam melakukan tugas Bapas sebagai petugas kemasyarakatan dan ketersediaan pelatih atau instruktur yang berpengalaman khususnya dalam bidang keterampilan bagi para klien pemasyarakatan.Kendala lain adalah dengan luasnya wilayah kerja juga berpengaruh terhadap jumlah pembimbing kemasyarakatan anak yang ada.

\subsection{Faktor Kesadaran Hukum Masyarakat.}

Berbicara mengenai hukum, maka harus juga membicarakan tentang masyarakat, karena tidak mungkin hukum tersebut terlepas dari masyarakat. Ada sebuah teori yang menjelaskan hal tersbut, yakni teori yang dikemukakan oleh Carl von Sagivny, dimana menurutnya "das Recht wird nicht gemacht, est ist und wird mit dem Volke" atau terjemahannya bahwa hukum itu tidak dibuat melainkan 
tumbuh dan berkembang bersama masyarakat. ${ }^{7}$ Sebagaimana diungkapkan oleh Mochtar Kusumaatmadja, bahwa hukum yang dibuat harus sesuai atau memperhatikan kesadaran hukum masyarakat. Penyimpangan dari hal tersebut diatas menimbulkan kondisi penegakan hukum (law enforcement) menjadi stagnan.

Faktor kesadaran hukum masyarakat terkait dengan budaya hukum masyarakat adalah meliputi pandangan, kebiasaan maupun perilaku dari masyarakat mengenai pemikiran nilai-nilai dan pengharapan dari sistem hukum yang berlaku, dengan perkataan lain, budaya hukum itu adalah iklim dari pemikiran sosial tentang sebagaimana hukum itu diaplikasikan, dilanggar atau dilaksanakan. Kultur hukum (legal culture) menyangkut budaya yang merupakan sikap manusia (termasuk budaya hukum aparat penegak hukumnya) terhadap hukum dan sistem hukum.

Salah satu kendala terhambatnya penerapan diversi adalah paradigma masyarakat yang beranggapan bahwa setiap tindak kejahatan yang dilakukan ada balasannya (restributif justice). Sehingga jika ada anak yang melakukan perilaku menyimpang harus dilaporkan ke pihak kepolisian untuk dilanjutkan ke proses persidangan. Persoalan yang besar pengaruhnya terhadap pelaksanaan diversi, adalah kuatnya pola pikir masyarakat yang selalu pandangan bahwa setiap persoalan yang menyangkut pelanggaran hukum harus diselesaikan melalui prosedur hukum formal. Dalam arti karena diversi harus ada kesepakatan antara korban beserta keluarga serta pelaku dan keluarganya, maka pihak korban enggan bahkan pada umumnya menolak untuk dilakukan diversi dalam menyelesaikan perkara. Ide diversi masih terkendala dengan adanya pandangan masyarakat yang cenderung dendam dan ingin melakukan pembalasan terhadap pelaku kejahatan, termasuk pada pelaku anak.

\section{Kesimpulan}

Diversi bukanlah sebuah upaya damai antara anak yang berkonflik dengan hukum dengan korban atau keluarganya akan tetapi sebuah bentuk pemidanaan terhadap anak yang berkonflik dengan hukum dengan cara non formal yang wajib dilakukan sebelum anak dihadapkan dengan hukum, namun pada kenyataannya saat ini masih kurang optimal dilaksanakan oleh aparat penegak hukum kita karena terbentur oleh aturan-aturan yang belum spesifik tentang diversi anak bagi setiap instansi penegak hukum didalam sistem peradilan pidana. Faktor-faktor yang mempengaruhi pelaksanaan diversi dalam restorative justice pada sistem peradilan pidana anak di Kabupaten Tana Toraja adalah faktor substansi hukum, sumber daya manusia aparat penegak hukum yang belum dapat memahami dengan baik mengenai diversi, sarana dan prasarana yang belum lengkap, faktor kesadaran hukum masyarakat yang masih rendah dalam melaksanakan diversi, dukungan dan kerjasama antar lembaga belum optimal, dan korban/keluarga korban belum dapat menerima secara baik mengenai diversi.

\footnotetext{
${ }^{7}$ Soerjono Soekanto, 2012, Sosiologi Suatu Pengantar. Rajawali Pers, Jakarta, hal. 144
} 


\section{REFERENSI}

Abdussalam dan DPM Sitompul, 2007, Sistem Peradilan Pidana, Jakarta: Restu Agung. Apong Herlina, 2004, Perlindungan Terhadap Anak yang Berhadapan dengan Hukum, Buku Saku untuk Polisi, Jakarta: Unicef.

Marlina, 2008, Penerapan Konsep Diversi Terhadap Anak Pelaku Tindak Pidana Dalam Sistem Peradilan Pidana Anak, Jurnal Equality, v13n1.

2010, Pengantar Konsep Diversi dan Restoratif Justice dalam Hukum Pidana, Medan: USU Press.

Muladi dan Barda Nawawi Arif, 1992, Teori-Teori dan Kebijakan Pidana, Bandung: Alumni.

Romli Atmasasmita, 2010, Sistem Peradilan Pidana Kontemporer, Bandung: Mandar Maju.

Soerjono Soekanto, 2012, Sosiologi Suatu Pengantar. Jakarta: Rajawali Pers. 